This is a self-archived version of an original article. This version may differ from the original in pagination and typographic details.

Author(s): Naveed, Nasir; Watanabe, Chihiro; Neittaanmäki, Pekka

Title: Co-Evolutionary Coupling via a Digital-bio Ecosystem : A Suggestion for a New R\&D Model in the Digital Economy

Year: 2019

Version: Published version

Copyright: (c) The Authors, 2019.

Rights: CC BY 4.0

Rights url: https://creativecommons.org/licenses/by/4.0/

Please cite the original version:

Naveed, N., Watanabe, C., \& Neittaanmäki, P. (2019). Co-Evolutionary Coupling via a Digital-bio Ecosystem : A Suggestion for a New R\&D Model in the Digital Economy. International Journal of Managing Information Technology, 11(2), 65-87. https://doi.org/10.2139/ssrn.3404007 


\title{
Co-Evolutionary Coupling Via A Digital-Bio ECOSYSTEM - A SUGGESTION FOR A NEW R\&D MODEL IN THE DIGITAL ECONOMY
}

\author{
Nasir Naveed ${ }^{1}$, Chihiro Watanabe ${ }^{1,2}$, Pekka Neittaanmäki ${ }^{1}$ \\ ${ }^{1}$ Faculty of Information Technology, University of Jyväskylä, Finland \\ 2 International Institute for Applied Systems Analysis (IIASA), Austria
}

\begin{abstract}
Driven by digital solutions, the bioeconomy has taken major steps forward in recent years toward achievement of the long-lasting goal of transition from a traditional fossil economy to a circular economy. The coupling of digitalization and the bioeconomy is leading toward a digitalized bioeconomy that can satisfy a shift in people's preferences for eco-consciousness, which in turn induces coupling of up-down stream operation in the value chain.
\end{abstract}

This dual couplings has led to a new $R \& D$ model that absorbs external innovation resources from a broad value chain and assimilates them into various entities.

In light of the increasing significance of such a new $R \& D$ model that may avoid the dilemma between $R \& D$ expansion and productivity decline, this paper elucidated dynamism enabling dual couplings.

An empirical analysis of global forest-based bioeconomy firms was conducted, thereby providing an insightful suggestion with respect to dynamism emerging from a new R\&D model.

\section{KEYWORDS}

Co-evolutionary coupling, digitalized bioeconomy, R\&D model, circular economy, UPM,

\section{INTRODUCTION}

Driven by digital solutions, the bioeconomy is taking major steps forward in recent years toward achievement of the long-lasting goal of transition from a traditional fossil economy to a bioeconomy-based circular economy [1].

Almost 50 years have passed since the similar goal was proposed in Japan amidst an industrial society in the early 1970s with the world highest economic growth. Highly material-intensive and energy-intensive industries resulted in serious environmental problems which led to reexamination of industrial policy [2]. Recognizing the need for a change in direction, Japan formulated a new plan for its industrial development by proposing a shift to a knowledgeintensive industrial structure, which would place a lesser burden on the environment by depending less on energy and materials while depending more on technology [3].

In order to identify the basic concept of the required industrial structure, Japan's MITI (Ministry of International Trade and Industry) depended on the concept of industry-ecology as a comprehensive method for analyzing and evaluating the complex mutual relationship between human activities and its surrounding environment $[4,5]$. Industry-ecology inspired to recognize the following five basic principles for constructing a circular economy-oriented platform [6]: (i)

DOI : $10.5121 /$ ijmit.2019.11205 
International Journal of Managing Information Technology (IJMIT) Vol.11, No.2, May 2019

System boundaries, (ii) Relationships in the system, (iii) Redundancy in the system, (iv) Doseresponse relationships in the system, and (v) The need for self-control.

While the forest-based bioeconomy incorporates the potential broad cross-sectoral benefits with sophisticated function satisfying all these principles, the natural environment, locality constraints, and incessant challenge of distance have impeded the balanced development of this economy [7, $8,9,10]$

However, driven by digital solutions, the bioeconomy has taken big steps forward in recent years. Digitalization has enabled real-time, end-to-end supply chain visibility, improved delivery accuracy as well as stock level optimization and alignment with demand planning.

Supported by the advanced digital innovation such as artificial intelligence (AI), machine learning, virtual reality (VR), augmented reality (AR), and big data analysis, the coupling of digitalization and bioeconomy is leading towards a digitalized bioeconomy that can satisfy the shift in people's preferences for eco-consciousness, which in turn induces coupling of up-down stream operation in the value chain $[11,12,13]$. This dual coupling enables VR and AR to practicalbusiness.

Thus, the co-evolution of the coupling of digitalization and bioeconomy and of upstream and downstream operations is transforming the forest-based bioeconomy into a digital platform industry, which accomplishes the required basic principles postulated half a century ago in reality, and explores a new four-dimensional sphere beyond the existing concept of the digital innovation. To date, while many studies analyzed the systems nature of the forest-based bioeconomy $[10,14$, $15,16,17,18]$, none has undertaken the empirical analysis with a view to demonstrate the above coevolutionary coupling.

This paper aimed at conceptualizing the above new four dimensional sphere. By means of stepwise empirical analyses taking 50 global forest-based bioeconomy leaders, elucidation of a unique feature of the co-evolutionary coupling toward circular economy was attempted.

An insightful suggestion supportive to constructing disruptive business model in the digital economy $[19,20]$ was thus provided.

Organization of this paper is as follows: Section 2 over reviews global new streams of the digitalized bioeconomy. Market value of the digitalized bioeconomy is examined in Section 3. Section 4 analyzes co-evolutionary coupling. Section 5 summarizes the noteworthy findings, policy suggestions, and future research.

\section{Digitalized Bioeconomy - GLOBAL NEW STREAMS}

Given a transformative endeavor of the digitalized bioeconomy identical to geopolitical regions, leading challenges in the region were identified first from both growth potential and business prospects.

\subsection{DEVELOPMENT TRAJECTORY OF GLOBAL BioECONOMY FiRMS}

In line with the advancement of the digital economy, global bioeconomy firms have been endeavoring digital solutions, which inevitably urges them $R \& D$-driven income-seeking strategy as illustrated in Fig. 1. Fig. 1 illustrates $R \& D$-driven operating income $(O I)$-seeking trajectory in 50 global bioeconomy firms encompassing forest, paper and packaging firms in 2017 (see the details of the 50 firms in Table A1 in the Appendix). 


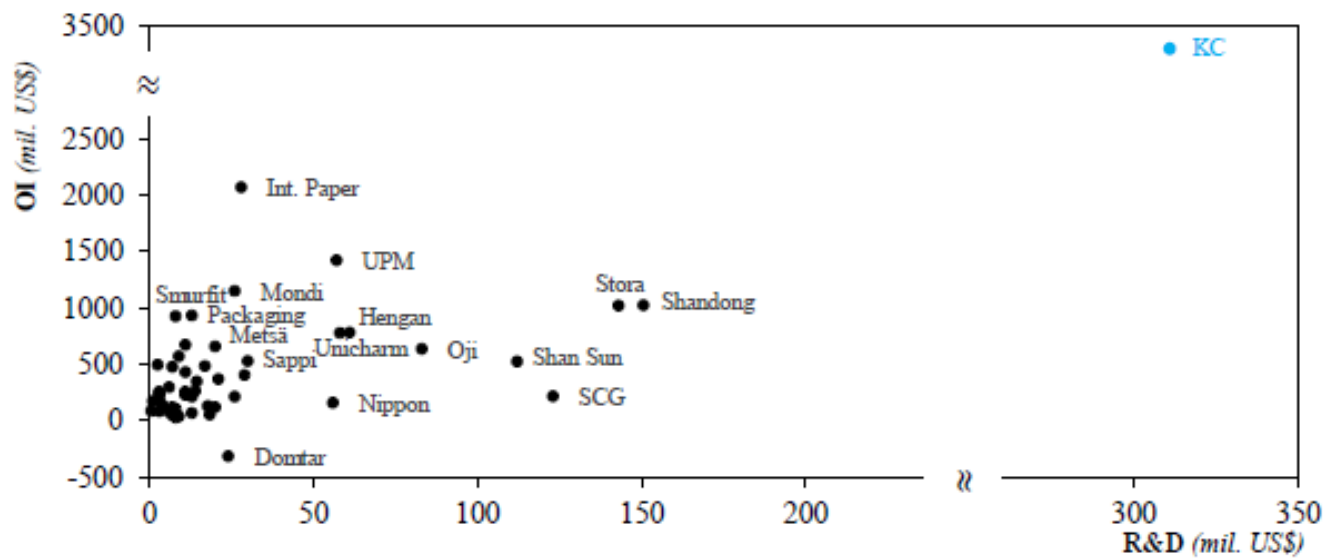

Figure 1. R\&D-driven $O I$-seeking trajectory in 50 global bioeconomy firms (2017).

Given that R\&D increase depends on revenues (sales) increase, this strategy leads these firms to $\mathrm{R} \& \mathrm{D}$ and sales-driven income (operating income) seeking trajectory ( $R$-S-driven OI-seeking trajectory $)^{1}$.

Table 1 analyzed this trajectory in 50 global bioeconomy firms in 2017 by applying their $O I$ increasing trajectory to $R$-S-driven logistic growth function.

Table 1. Development trajectory of operating income in 50 global bioeconomy firms in 2017.

$O I=$

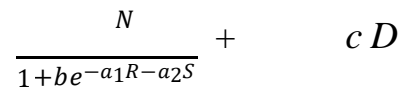

\begin{tabular}{ccccccc}
\hline$N$ & $a_{1}$ & $a_{2}$ & $b$ & $c$ & $a d j . R^{2}$ & $D$ \\
\hline 6360.86 & 0.004 & 0.0001 & 29.02 & -729.68 & 0.828 & Domtar \\
$(1.39)^{*}$ & $(2.39)$ & $(5.46)$ & $(5.35)$ & $(-2.85)$ & & \\
\hline
\end{tabular}

$O I$ : operating income; $N$ : carrying capacity; $R$ : R\&D expenditure; $S$ : sales; $D$ : dummy variable; $a 1, a 2, b$ and $c$ : coefficients.

The figures in parentheses indicate the t-statistics: all are significant at the $1 \%$ level except *: 5\%.

Table 1 demonstrates statistically significant where respective coefficients indicate $a_{1}$ and $a_{2}$ : velocity of $O I$ increase; $b$ : initial state of $O I$ level; and $c$ : adjustment of Domtar's low level of $O I$, which is exceptional to other 49 firms, in the regression analysis.

${ }^{1}$ Revenues and net income can be appropriated by sales and operating income, respectively as Revenues = Sales + Interest income + Dividend income.

Net income $=$ Operating income + investment income - interest expense + one-time extraordinary income - one-time extraordinary expenses - taxes

Table 1 suggests that rapid $O I$ increase in 50 global bioeconomy firms in the digital economy significantly depends on R\&D and sales.

Inspired by this finding, with the understanding that rapid income increase is decisive to global firms in the digital economy, Table 2 identifies top 20 prospecting global bioeconomy firms from 
International Journal of Managing Information Technology (IJMIT) Vol.11, No.2, May 2019

growth potential. This potential was analyzed based on the potential of rapid $O I$ increase by utilizing a synchronized index $(S I)$ that demonstrates the velocity of $O I$ increase.

Table 2. Top 20 prospecting global bioeconomy firms in 2017.

\begin{tabular}{|c|c|c|c|c|c|c|c|c|c|c|c|c|c|c|c|}
\hline $\begin{array}{c}S I \\
\text { rank }\end{array}$ & Firm & Country & $\begin{array}{c}S I \\
\text { value }\end{array}$ & OI & Sales & R\&D & $\overline{\mathrm{OI} / \mathrm{S}}$ & $R / S$ & $\mathrm{OI} / \mathrm{R}$ & \begin{tabular}{|l} 
OI \\
rank
\end{tabular} & $\begin{array}{l}\text { Sales } \\
\text { rank }\end{array}$ & $\begin{array}{l}\text { R\&D } \\
\text { rank }\end{array}$ & \begin{tabular}{|l|}
$\mathrm{OI} / \mathrm{S}$ \\
$\mathrm{rank}$
\end{tabular} & R/S rank & $\begin{array}{l}\mathrm{OI} / \mathrm{R} \\
\text { rank }\end{array}$ \\
\hline 1 & KC & US & 3.07 & 3299 & 18259 & 311 & 0.18 & 0.017 & 10.61 & 1 & 1 & 2 & 3 & 4 & 13 \\
\hline 2 & Int. Paper & US & 2.29 & 2069 & 21743 & 28 & 0.10 & 0.001 & 73.89 & 2 & 2 & 11 & 11 & 19 & 2 \\
\hline 3 & Stora & Finland & 1.70 & 1019 & 11325 & 143 & 0.09 & 0.013 & 7.13 & 6 & 6 & 3 & 13 & 5 & 16 \\
\hline 4 & Oji & Japan & 1.62 & 633 & 12838 & 83 & 0.05 & 0.006 & 7.63 & 11 & 3 & 6 & 16 & 7 & 14 \\
\hline 5 & UPM & Finland & 1.36 & 1419 & 11285 & 57 & 0.13 & 0.005 & 24.89 & 3 & 3 & 8 & 7 & 10 & 8 \\
\hline 6 & Nippon & Japan & 1.16 & 157 & 9330 & 56 & 0.02 & 0.006 & 2.80 & 19 & 9 & 9 & 19 & 8 & 18 \\
\hline 7 & Sumitomo & Japan & 1.06 & 481 & 9926 & 17 & 0.05 & 0.002 & 28.29 & 15 & 6 & 16 & 17 & 17 & 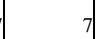 \\
\hline 8 & Shandong & China & 1.04 & 1023 & 4417 & 151 & 0.23 & 0.034 & 6.80 & 5 & 18 & 2 & 1 & 3 & 15 \\
\hline 9 & Smurfit & Ireland & 1.00 & 924 & 9653 & 8 & 0.10 & 0.001 & 115.50 & 8 & 7 & 20 & 10 & 20 & \\
\hline 10 & Mondi & UK & 0.90 & 1148 & 8000 & 26 & 0.14 & 0.003 & 44.15 & 4 & 9 & 12 & 5 & 14 & 5 \\
\hline 11 & Unicharm & Japan & 0.80 & 774 & 5721 & 58 & 0.14 & 0.010 & 13.34 & 9 & 12 & 7 & 6 & 6 & 12 \\
\hline 12 & SCG & Thailand & 0.74 & 212 & 2517 & 123 & 0.08 & 0.049 & 1.72 & 17 & 20 & 0 & 14 & 1 & 19 \\
\hline 13 & Shan Sun & China & 0.73 & 523 & 2796 & 112 & 0.19 & 0.040 & 4.67 & 14 & 19 & 5 & 2 & 2 & 17 \\
\hline 14 & Packaging & US & 0.70 & 931 & 6445 & 13 & 0.14 & 0.002 & 71.62 & 7 & 10 & 17 & 4 & 16 & 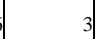 \\
\hline 15 & DS & UK & 0.65 & 570 & 6153 & 9 & 0.09 & 0.001 & 63.33 & 12 & 11 & 19 & 12 & 18 & \\
\hline 16 & Sappi & S. Africa & 0.65 & 526 & 5296 & 30 & 0.10 & 0.006 & 17.53 & 13 & 14 & 10 & 9 & 9 & 9 \\
\hline 17 & Metsä & Finland & 0.65 & 655 & 5682 & 20 & 0.12 & 0.004 & 32.75 & 10 & 13 & 15 & 8 & 13 & 6 \\
\hline 18 & Domtar & Canada & 0.61 & -317 & 5157 & 24 & -0.06 & 0.005 & -13.21 & 20 & 15 & 13 & 20 & 11 & 20 \\
\hline 19 & Sonoco & US & 0.59 & 367 & 5037 & 21 & 0.07 & 0.004 & 17.48 & 16 & 16 & 14 & 15 & 12 & 10 \\
\hline 20 & Rengo & Japan & 0.54 & & 4863 & 13 & 0.04 & 0.003 & 16.23 & 18 & 17 & 18 & 18 & 15 & 11 \\
\hline
\end{tabular}

SI: Synchronized index; $S I$ value $=a_{1} R+a_{2} S=0.004 R+0.0001 S$ See the full name of the firm in Table A1 in the Appendix.

\subsection{LEADING BIOECONOMY FIRMS IN GEOPOLITICAL REGION}

Given the geopolitical significance of bioeconomy firms in the digital economy, Table 3 classified top 20 prospecting firms into four regions: America, Europe, Asia and Africa. In order to evaluate the comparative advantage and prospects of values that top firms will realize, Table 3 also compares market capitalization which represents business prospects [21] between the top two $S I$ value firms in each respective region over the last 5 years. 
International Journal of Managing Information Technology (IJMIT) Vol.11, No.2, May 2019

Table 3. Geopolitical distribution of prospecting bioeconomy firms in 2017.

\begin{tabular}{|c|c|c|c|c|c|c|}
\hline \multirow[t]{2}{*}{ Region } & \multirow{2}{*}{ Firms (SI value, numbers indicate $S I$ rank among 20 firms) } & \multicolumn{5}{|c|}{ Market capitalization (mil. US\$, 2010 fixed prices) } \\
\hline & & 2013 & 2014 & 2015 & 2016 & 2017 \\
\hline \multirow{3}{*}{ America } & 1. $\mathrm{KC} \mathrm{(3.07)}$ & 35219 & 38692 & 35447 & 44884 & 40695 \\
\hline & 2. $\quad$ Int. Paper (2.29) & 18534 & 20226 & 19309 & 15714 & 20747 \\
\hline & 14. Packaging (0.70), 18. Domtar (0.61), 19. Sonoco (0.59) & & & & & \\
\hline \multirow{4}{*}{ Europe } & 3. $\quad$ Stora $(1.70)$ & 7058 & 7069 & 6539 & 7908 & 10294 \\
\hline & 5. $\quad$ UPM (1.36) & 7966 & 8749 & 9082 & 12180 & 13648 \\
\hline & 9. Smurfit (1.00), 10. Mondi $(0.90), 15$. DS $(0.65), 17$. Metsä $(0.65)$ & & & & & \\
\hline & 4. $\quad$ Oji (1.62) & 3609 & 4351 & 4029 & 4059 & 4552 \\
\hline \multirow{2}{*}{ Asia } & 6. $\quad$ Nippon (1.16) & 1783 & 2147 & 1712 & 2107 & 2045 \\
\hline & $\begin{array}{l}\text { 7. Sumitomo (1.06), 8. Shandong (1.04), 11. Unicharm (0.80), 12. SCG } \\
(0.74), 13 \text {. Shan Sun }(0.73), 20 \text {. Rengo }(0.54)\end{array}$ & & & & & \\
\hline Africa & 16. Sappi (0.65) & 1106 & 1611 & 1165 & 1982 & 2441 \\
\hline
\end{tabular}

Based on the comparison both by growth potential and business prospects using $S I$ values and market capitalization between top 2 SI value firms in the region, following 4 firms with higher market capitalization were chosen that represent prospecting firms in each respective region both growth potential and business prospects as summarized in Table 4.

Table 4. Leading prospecting bioeconomy firms in the 4 regions in 2017.

\begin{tabular}{|c|c|c|c|c|c|c|c|c|}
\hline Firm & Country & $S I$ value & OI & Sales & \begin{tabular}{l|l}
$\mathrm{R} \& \mathrm{D}$ & $\mathrm{OI} / \mathrm{S}$
\end{tabular} & $\mathbf{R} / \mathbf{S}$ & OI/R & Business type / segments \\
\hline $\mathrm{KC}$ & US & 3.07 & 3299 & 18259 & 3110.18 & 0.017 & 10.61 & $\begin{array}{l}\text { Personal care (disposable diapers, training and youth } \\
\text { pants, swimpants, baby wipes, feminine and } \\
\text { incontinence care products, and other related } \\
\text { products) Consumer tissues (facial and bathroom } \\
\text { tissue, paper towels, napkins and related products) } \\
\text { K- C professional (wipers, tissue, towels, apparel, } \\
\text { soaps } \\
\text { and sanitizers.) }\end{array}$ \\
\hline UPM & Finland & 1.36 & 1419 & 11285 & 570.13 & 0.005 & 24.89 & $\begin{array}{l}\text { Forest-based bio products (biochemicals, } \\
\text { biocompo } \\
\text {-sites, biofuels, energy, labels, pulp and paper, } \\
\text { plywood and timber). } \\
\text { Acquisition of Myllykoski and Rhein Papier in 2010 } \\
\text { accelerated the transformation into circular } \\
\text { economy- based business model consists of five } \\
\text { principles: (i) circular supplies, (ii) resource } \\
\text { recovery, (iii) product life extension, (iv) sharing } \\
\text { platforms, and (v) products } \\
\text { as a service. }\end{array}$ \\
\hline Oji & Japan & 1.62 & 633 & 12838 & 830.05 & 0.006 & 7.63 & $\begin{array}{l}\text { Household and industrial materials (packaging } \\
\text { materials and products, household papers, disposable } \\
\text { diapers) Functional materials (speciality papers, } \\
\text { thermal papers, adhesive products) Forest resources } \\
\text { (pulp, power generation, lumber processing) } \\
\text { Printing and communication (newsprint, printing } \\
\text { and publication paper, copying paper) }\end{array}$ \\
\hline Sappi & South Africa & 0.65 & 526 & 5296 & 300.10 & 0.006 & 17.53 & $\begin{array}{l}\text { Forest-based bio products (printing paper, } \\
\text { packaging and speciality papers, casting and release } \\
\text { paper, dissolving wood pulp, biomaterials, bioenergy) }\end{array}$ \\
\hline
\end{tabular}




\section{MARKeT VAlue OF Digitalized BioEconoMY}

\subsection{MARKET CAPITALIZATION}

Aiming at measuring the potential and prospects of market value of digitalized bioeconomy in transition, market capitalization $(\mathrm{MC})$ and its sales ratio $(\mathrm{MC} / \mathrm{S})$ were used. $\mathrm{MC}$ is obtained by multiplying the number of a publicly traded firm's outstanding shares by the current share price. Since this represents the comparative advantage and prospects of values that the firm will realize, it is generally highly appraised as a good indicator of firms about their business prospects [21].

Fig. 2 illustrates trend in MC (in logarithmic scale) in the 4 firms representing the 4 geopolitical regions. Fig. 2 demonstrates KC's highest level followed by UPM, Oji and Sappi.

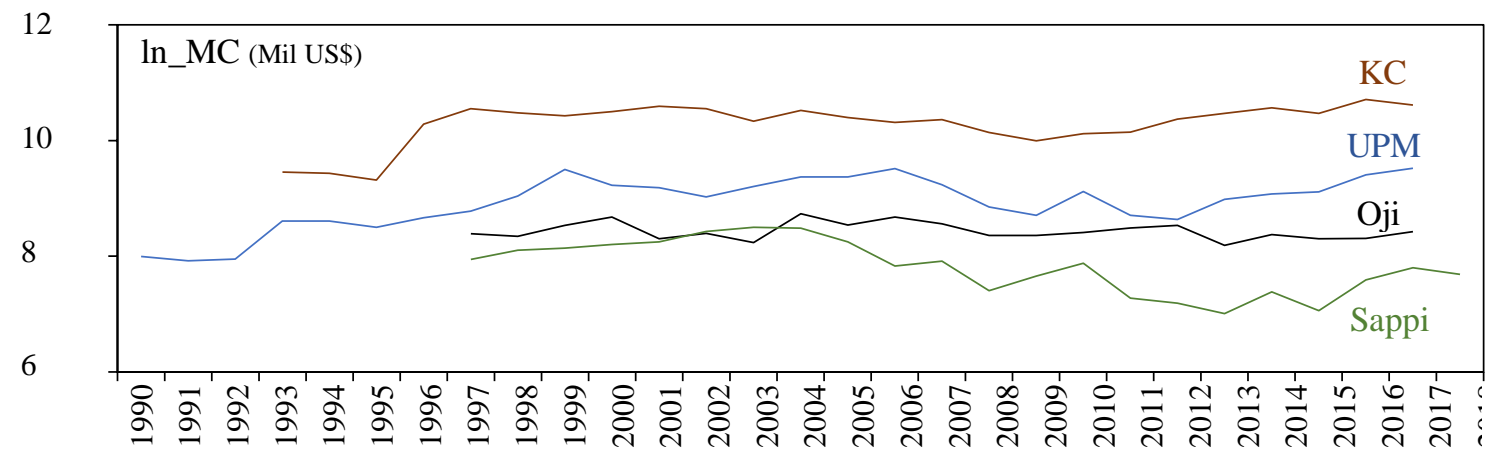

Figure 2. Trend in MC in the 4 firms in logarithmic scale.

However, if we compare the recent growth rate, we note UPM's conspicuously high growth rate over the last 5 years as demonstrated in Figs. 3 and $\mathbf{4}$.

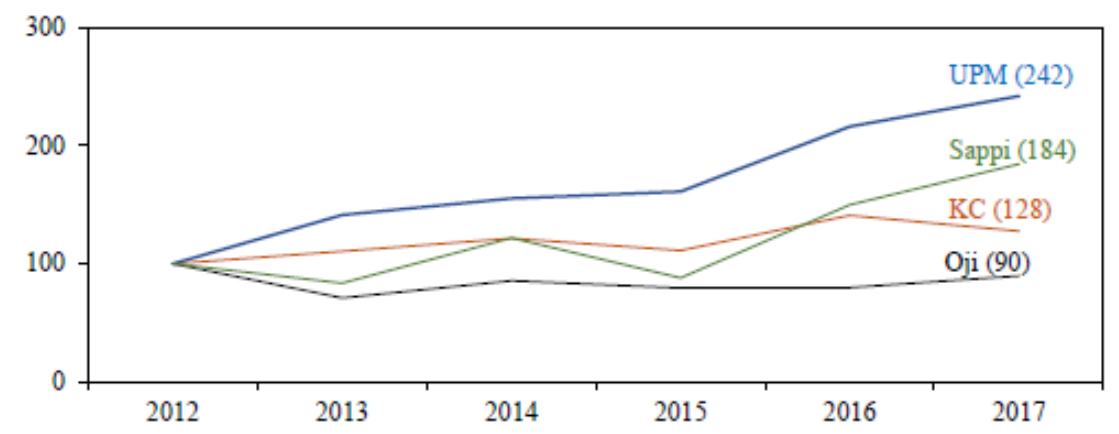

Figure 3. Trend in increase ratio of MC in the 4 firms $(2012-2017)-$ Index: $2012=100$.

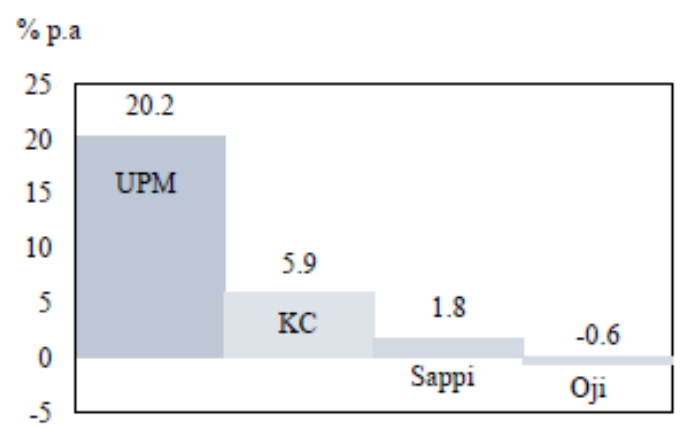

Figure 4. Average growth rate of MC in the 4 firms (2013-2017). 


\subsection{Price-To-Sales Ratio}

While MC represents the value of business prospects, it depends not only on qualitative value of the business prospects but also on the quantity of business activities. Therefore, in case when evaluating the value of business prospects placed on firm's sales, the price-to-sales ratio (PSR) is used. PSR is a ratio of firm's market capitalization and its sales $(\mathrm{MC} / \mathrm{S})$, thereby used as an indicator of the value placed on firm's sales. PSR is also known as a sales multiple. Contrary to enterprise value-to-sales ratio (EVSR), it is supportive to make a comparative prospects assessment of firm's business model.

Figs 5 and 6 demonstrate clear contrast between UPM's rapid increase and KC's decline in PSR.

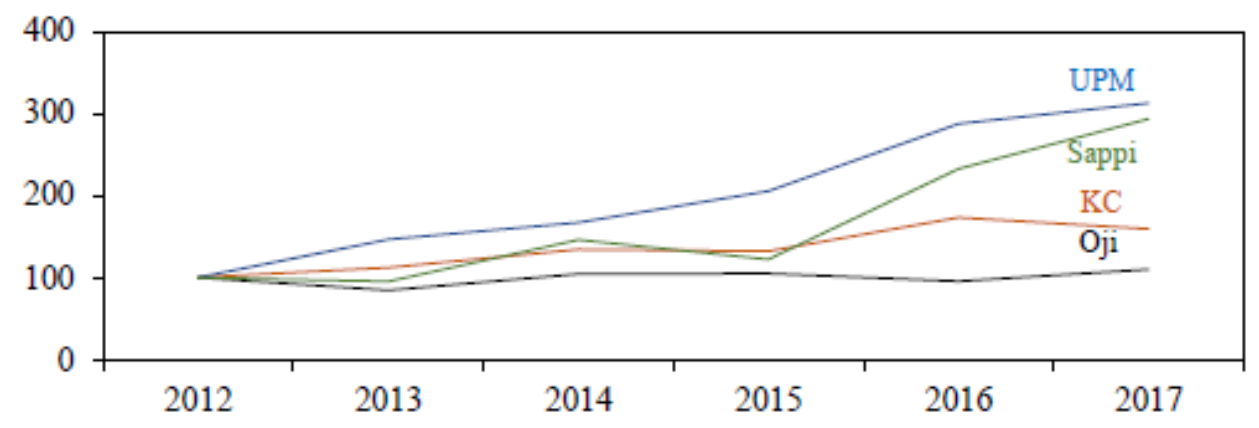

Figure 5. Trend in increase ratio of PSR in the 4 firms (2012-2017) - Index: $2012=100$.

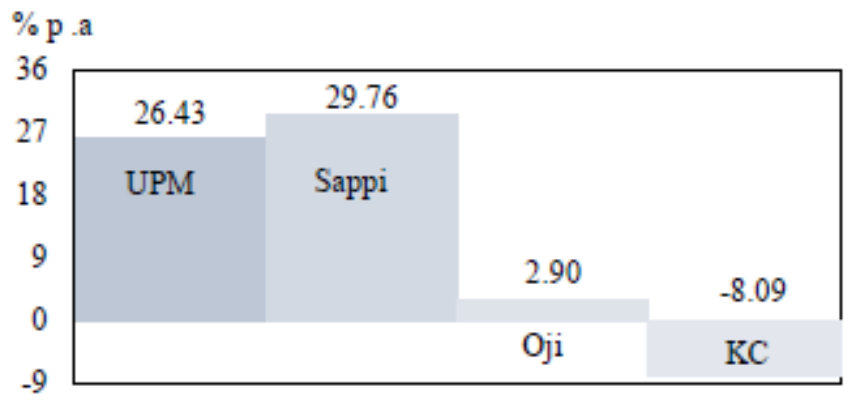

Figure 6. Average growth rate of PSR in the 4 firms (2013-2017).

\subsection{Governing FACTORS OF MARKET CAPITALIZATION}

Market capitalization is a dependent variable determined by other variables, both by indigenous efforts and external stimulations. Co-evolutional advancement of these efforts and stimulations are essential to sustainable growth of MC and also of PSR.

\subsubsection{Indigenous Efforts}

In conducting a comparative prospects assessment of firm's business model, following indigenous efforts should be taken for governing factors decisive to MC [21]:

\section{(1) Sales and Operating Income}

A firm's growth, generally measured by the rate of growth in sales, has a positive effect on the market value of a firm as this growth usually leads to an increase in operating income and R\&D. Since operating income (close to net income as net income $=$ operating income + investment income - 
interest expense + one-time extraordinary income - one-time extraordinary expenses - taxes) enables firms new activities and/or rewarding to shareholders by providing dividend, investors expect the firm to do well in the future. Therefore, if operating income goes up, the stock price and subsequently the MC increases.

\section{(2) R\&D}

While R\&D decreases the firm's profit in the short term, it creates the potential for higher profits in the medium and long term. Therefore, its increase is considered a positive sign for the firm's future profits leading to the MC increases. However, since R\&D incorporates a pregnant period before commercialization and also a risk of failure, $R \& D$ challenge without investors' confidence results in the MC decreases [22,23].

\subsubsection{External Stimulations}

In addition to the above indigenous efforts, the $\mathrm{MC}$ as a dependent variable, is subject to external stimulations such as external market conditions both global and local. Furthermore, as a consequence of the unique feature of value chain structure of the forest-based bioeconomy, the $\mathrm{MC}$ of the upstream firm is subject to the coupling effects with the downstream environments [24].

\section{(1) External Market Conditions}

\section{1) Global Market Conditions}

(i) Macro-economic factors such as interest rates, inflation, economic growth, trends in oil prices, and exchange rates.

(ii) Political factors such as control of the government, elections, and also uncertainty stemmed from political circumstances change.

(iii) Natural and man-made disasters with economic consequences.

\section{2) Local Market Conditions}

Irregular happening identical to the firm such as changes in business, administration system, acquisition, and geo-political changes identical to the firm.

\section{(2) Coupling Effects with Downstream Firms}

Coupling effects with downstream environments cannot be overlooked as a consequence of the economy with value chain structure. In line with the advancement of the digital economy and subsequent increasing dependence on digital solution, these effects have been significantly increasing [10].

\subsection{InSTITUTIONAL STRUCTURE GOVERNing LEADING FOREST-BASEd BIOECONOMY FIRMS}

Following the above review, MC for leading forest-based bioeconomy firms can be depicted as follows:

$M C=F(S, O I, R, E x, C E)$

where $S$ : sales; $R D$ : R\&D investment; $E x$ : external market conditions; $C E$ : coupling effects with downstream firms. 
Given the $R$-S-driven OI-seeking trajectory in global bioeconomy firms as reviewed in Table 1, $O I$ and strong inducement by $R$ are considered to provide significant impacts on MC, and $S$ can be treated as a dependent variable of $O I$ and $R$ in these impacts in leading forest-based bioeconomy firms. Therefore, equation (1) can be transformed into equation (2) as follows:

$M C=F(O I, R, E x, C E)$

Translog (transcendental logarithmic) expansion on the first term:

$\ln M C=a+b \ln O I+c \ln R+d \ln E x+e \ln C E+f D$

where $a-f$ : coefficients; and $D$ : dummy variables for local market conditions (irregular happenings specific to the firm).

Utilizing equation (3), governing factors of MC in the 4 firms were analyzed as summarized in Table 5.

Table 5. Factors governing MC in the 4 firms.

$\ln M C=a+b \ln O I+c \ln R+d \ln E x+e \ln C E+f_{1} D_{1}+f_{2} D_{2}$

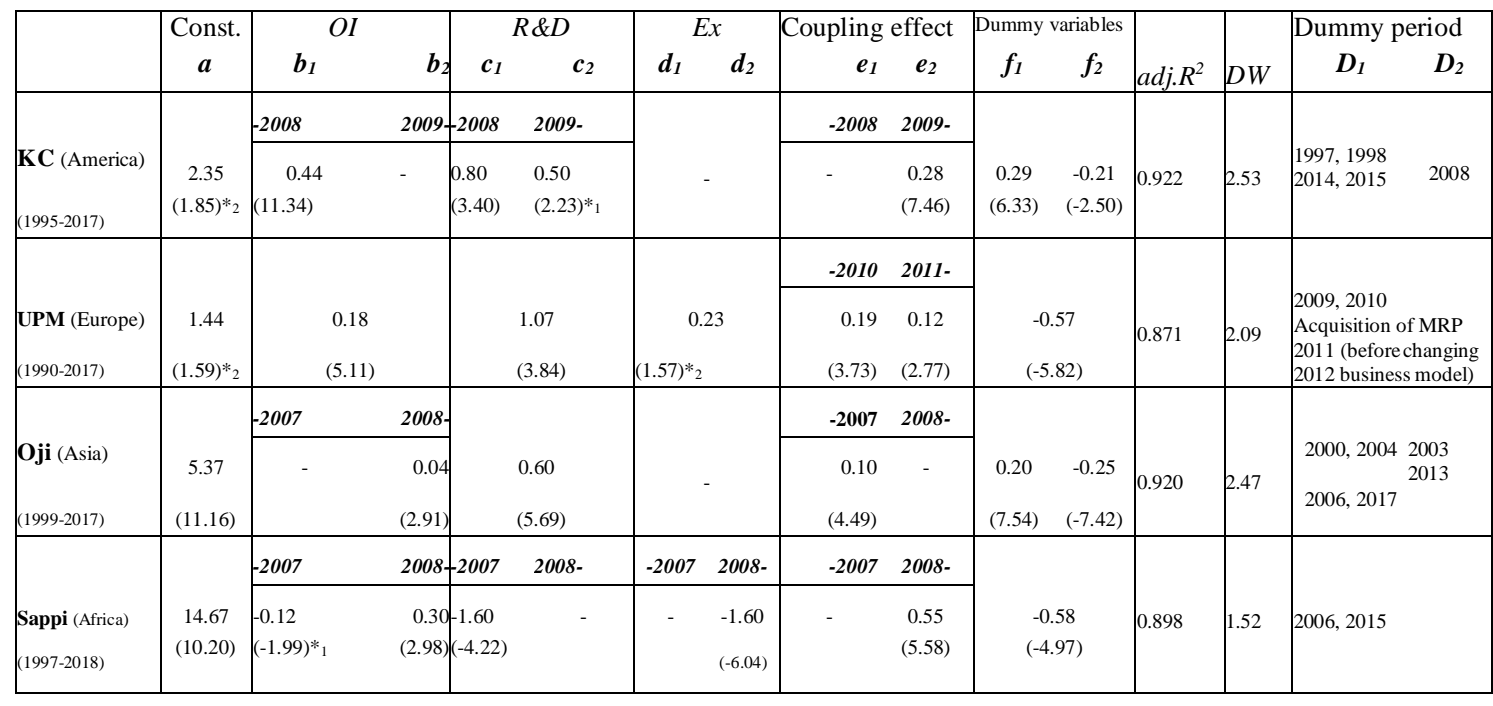

Coupling effect: correlation with Amazon's (downstream leader) stock price [10].

The figures in parentheses indicate $t$-statistics: all are significant at the $1 \%$ level except $* 1: 5 \%$, and $* 2$ : $10 \%$ level. Backward elimination method with $10 \%$ significant criteria was used.

Table 5 demonstrates the following notable features in the 4 firms (figures in the parentheses indicate elasticity):

(1) KC: (i) R\&D constantly induced MC (0.80, 0.50), (ii) OI inducement by 2008 (0.44) substituted to coupling effect after 2009 (0.28).

(2) UPM: (i) R\&D constantly induced MC strongly (1.07), (ii) OI constantly induced MC (0.18), (iii) Depended on coupling effect significantly (0.19, 0.12), (iv) External market conditions induced MC constantly (0.23).

(3) Oji: (i) R\&D constantly induced MC (0.60), (ii) Inducement of coupling effect by 2007 (0.10) substituted to $O I$ after $2008(0.04)$.

(4) Sappi: (i) $O I$ and coupling effect changed to positive inducement of MC after 2008 (0.3 
International Journal of Managing Information Technology (IJMIT) Vol.11, No.2, May 2019

and 0.55), (ii) $O I$ and $\mathrm{R} \& \mathrm{D}$ reacted negative inducement by 2007 (-0.12 and -1.60$)$ demonstrating failing to gain confidence from investors.

Among 4 firms, it is noted that UPM demonstrates sophisticated R\&D-driven virtuous cycle utilizing all resources including coupling with downstream and also external market inducement [25]. This led to its conspicuous performance as extremely higher MC/R after 2011, after the transition into circular-economy-based business model [26, 27], as demonstrated in Fig. 7.

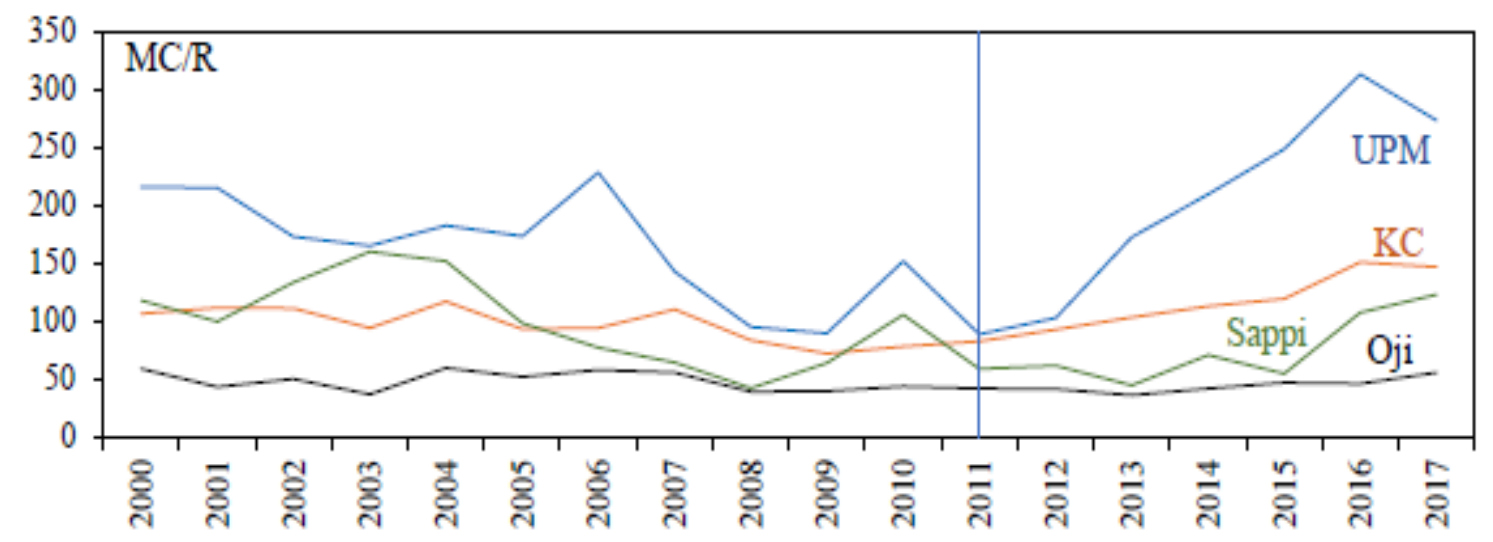

Figure 7. Trends in MC/R in the 4 firms (2000-2017).

\subsection{SOPHISTICATED R\&D-DRIVEN CO-EVOLUTION INITIATED BY UPM}

The above comparative analysis highlights a sophisticated R\&D-driven co-evolutional cycles utilizing external resources (downstream and external market) that UPM may incorporate as follows:

\section{(1) Sophisticated R\&D system in inducing MC}

(i) Highest $R \& D$ elasticity

UPM: 1.07; KC: $0.80 \sim 0.60$; Oji: 0.60; Sappi: negative

(ii) Maintains conspicuously high marginal productivity of R\&D to MC (MPRMC) as demonstrated in Fig. 8.

$$
\begin{aligned}
& \text { Elasticity of R\&D to MC } \quad \varepsilon_{M C R}=C=\frac{\partial \ln M C}{\partial \ln R} \\
& \text { MPRMC }=\frac{\partial M C}{\partial R}=C * \frac{M C}{R}=\frac{p_{R}}{p_{M C}}
\end{aligned}
$$

where $p R: \mathrm{R} \& \mathrm{D}$ price; $p M C$ : Stock price 


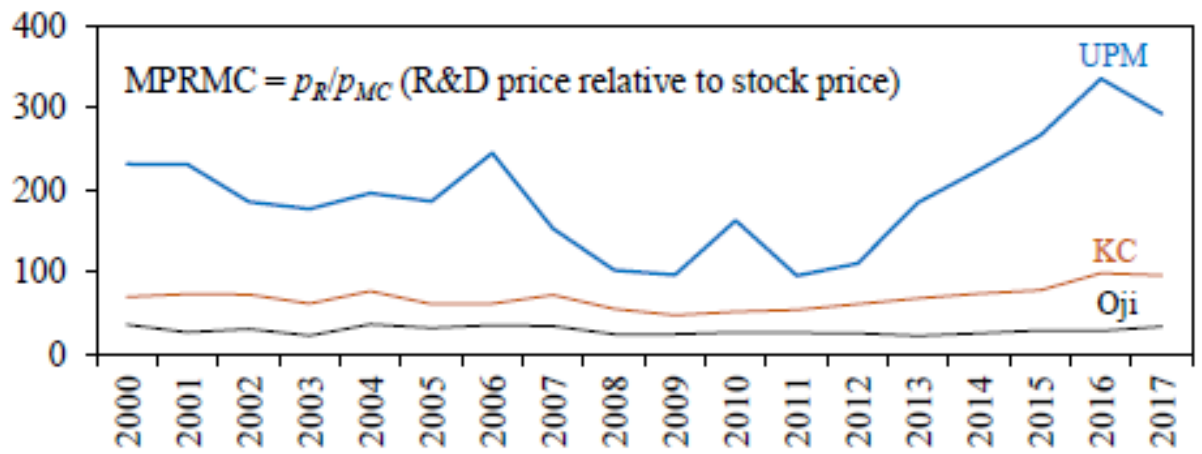

Figure 8. Trend in marginal productivity of R\&D to MC in the 3 firms (2000-2017).

(iii)Such high level of MPRMC induces PSR (MC/S) strongly as demonstrated in Table 6.

Table 6. Correlation between MPRMC and PSR in UPM (1990-2017)

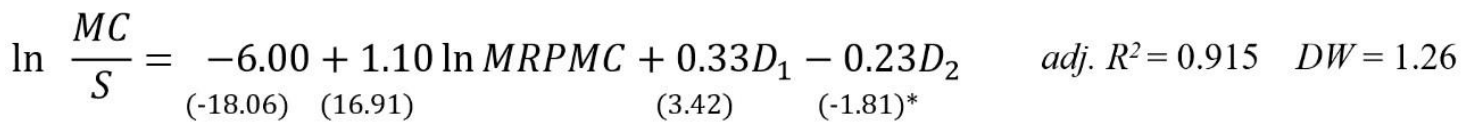

$D$ : dummy variables $\left(D_{1}: 2008,2009=1\right.$, others $=0 ; D_{2}: 2014=1$, others $\left.=0\right)$

The figures in parentheses indicate $t$-statistics: all are significant at the $1 \%$ level except $* 10 \%$ level.

Such an R\&D-driven MC and PSR (MC/S) inducing dynamism beyond the dilemma between $R \& D$ expansion and productivity decline prompts us an effective utilization of external resources for innovation and also self-propagating new market value creation as growth proceeds.

\section{(2) Well balanced resources allocation to MC creation}

$\mathrm{R} \& \mathrm{D}$ contributes to $\mathrm{MC}$ not only directly but also via $\mathrm{OI}$ (Table 1) as $\mathrm{OI}$ constantly induced MC.

\section{(3) Effective utilization of external resources in downstream and external market}

Downstream advancement and external market stimulation steadily contribute to MC.

These inducement prompts a co-evolutionary coupling in activating the above function. This can be attributed largely to UPM's new circular economy-seeking $R \& D$ challenge $[1,25,26,27,28]$ as highlighted in Table 7 by comparing with other global bioeconomy leaders.

Table 7. Major R\&D focus in the 4 firms.

\begin{tabular}{|l|l|}
\hline KC & $\begin{array}{l}\text { Kimberly Clark R\&D activities include researching materials and technology innovations to } \\
\text { deploy more circular business model. KC emphases on the zero-waste mindset across the value } \\
\text { chain and adopt the circular design principles to keep the post-consumer waste out of landfills. In } \\
\text { addition, they reduce and eliminate the materials of concerns to ensure the safety and well- } \\
\text { being of their customers. }\end{array}$ \\
\hline
\end{tabular}


International Journal of Managing Information Technology (IJMIT) Vol.11, No.2, May 2019

\begin{tabular}{|l|l|}
\hline UPM & $\begin{array}{l}\text { Eco-design approach is at core of R\&D efforts in the development of new technologies and } \\
\text { products. UPM invests on the bioeconomy innovations, forest biodiversity and circular } \\
\text { economy to create the sustainable solutions by minimizing the dependency on fossil-based } \\
\text { materials. UPM collaborates with customers, research institutions, universities and technology } \\
\text { providers to develop the creative circular economy solutions and user-friendly digital tools and } \\
\text { services. }\end{array}$ \\
\hline Oji & $\begin{array}{l}\text { Oji aims to develop the new possibilities, skills and high-tech materials in paper and forest } \\
\text { sector. They are devoting their R\&D efforts in developing cellulose fibres as it can potentially } \\
\text { be used in many fields such as construction, chemicals, packaging and so on. Oji is introducing } \\
\text { cutting-edge continuous process technology for biochemical material development as well as } \\
\text { highly-function film production technologies and medicinal plant cultivation techniques. }\end{array}$ \\
\hline Sappi & $\begin{array}{l}\text { Sappi's R\&D efforts are adhered to consolidation and growth in the industry through cost } \\
\text { competitiveness and optimization of equipment and forestry assets. They promote the } \\
\text { innovation culture to develop the sustainable solutions for the company. Sappi follows the } \\
\text { partnership approach and develop the long-term relationships with global firms and customers. } \\
\text { They are growing their nanocellulose competency due to its wide range of application in } \\
\text { construction, chemicals, personal and homecare products, composites and packaging papers. }\end{array}$ \\
\hline
\end{tabular}

\section{Co-Evolutionary Coupling}

\subsection{Sources EnAbling UPM's High PERFormanCe in MC CREATION}

Analysis in the preceding section suggests that UPM's notable high performance in MC creation can be attributed to its balanced contributing structure by $\mathrm{R} \& \mathrm{D}, O I$, coupling effect with downstream and also external market conditions as illustrated in Fig. 9. 


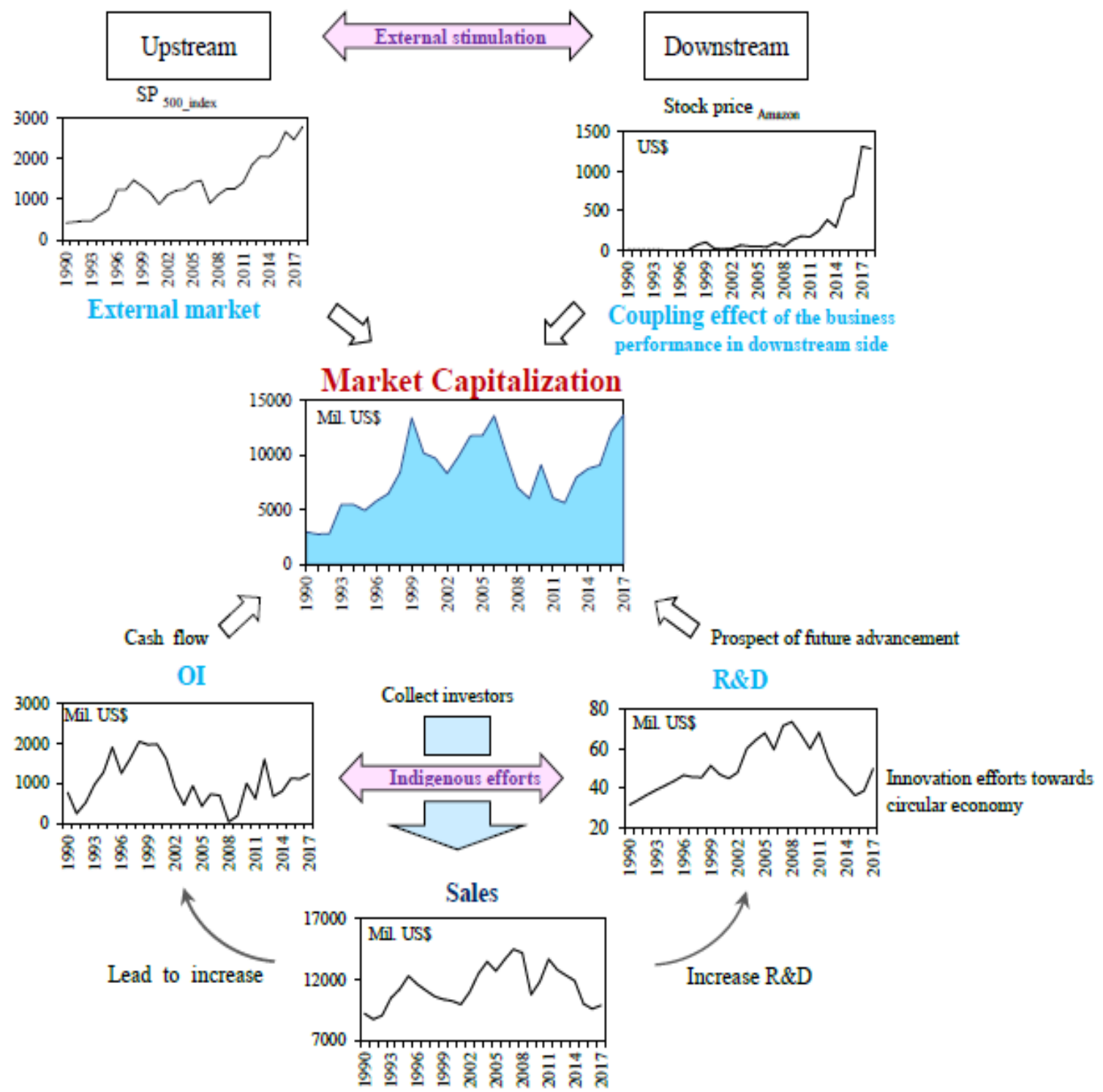

Figure 9. Co-evolutionary development of MC in UPM (1990-2017).

While Tables 5 and 6 demonstrate that R\&D and its price increase induce MC and PSR (MC/S) significantly, Tables 8 and $\mathbf{9}$ demonstrate that induced MC induces sales and PSR. In addition, induced sales induce $R \& D$, thus $R \& D$-driven virtuous cycle among them has been constructed.

Table 8. Correlation between MC and sales in UPM (1990-2017)

$$
\begin{aligned}
& \ln S=7.85+0.16 D_{1} \ln M C+0.15 D_{2} \ln M C+0.264 D_{3} \\
& \text { (24.13) (4.48) (4.15) (6.51) } \\
& \text { adj. } R^{2}=0.652 \\
& D W=1.07 \\
& D_{3}: \text { 1995, 2007, 2008, 2011, 2012, 2013, } 2014=1 \text {, others }=0 \text { ) }
\end{aligned}
$$

The figures in parentheses indicate $t$-statistics: all are significant at the $1 \%$ level. 
This regression suggests $\ln { }_{S}^{M C} \approx-7.85+0.85 \ln M C$

Table 9. Correlation between sales and R\&D in UPM (1990-2017).

$$
\begin{aligned}
& \ln R=-9.62+1.45 \ln S+0.38 D_{1}-0.25 D_{2} \\
& (-7.04)(9.90) \quad(3.54) \quad(-3.12) \\
& \text { adj. } R^{2}=0.799 \\
& D W=1.41
\end{aligned}
$$

$D$ : dummy variables $\left(D_{1}: 2009=1\right.$, others $=0 ; D_{2}: 1995,2014=1$, others $\left.=0\right)$

The figures in parentheses indicate $t$-statistics: all are significant at the $1 \%$ level.

\subsection{Assimilation of External Innovation Resources}

Such an R\&D-driven virtuous cycle notwithstanding the dilemma between R\&D expansion and productivity decline $[29,30]$ suggests a significant role that assimilated external resources in innovation, particularly soft innovation resources, may play. Prompted by such a hypothetical view, assimilation capacity and subsequent assimilated soft innovation resources were analyzed.

As reviewed earlier, MC for leading forest-based bioeconomy firms can be depicted as follows:

$\ln M C=a+b \ln O I+c \ln R D+d \ln E x+e \ln C E+f D$

Here, gross $\mathrm{R} \& \mathrm{D}$ incorporates both indigenous $\mathrm{R} \& \mathrm{D}\left(R_{i}\right)$ and assimilated soft innovation resources (SIRs) as follows where $z$ is assimilation capacity.

$$
\begin{aligned}
& R D=R_{i}+z S I R s=R_{i}\left(1+z \frac{S I R s}{R_{i}}\right) \quad z \frac{\text { SIRs }}{R_{i}} \ll 1 \\
& \therefore \ln R D=\ln R_{i}\left(1+z \frac{\text { SIRs }}{R_{i}}\right) \approx \ln R_{i}+z \frac{\text { SIRs }}{R_{i}}
\end{aligned}
$$

Where SIRs can be represented by ID (Internet dependence) as SIRs can be considered a condensate and crystal of the advancement of the Internet [29, 30].

By synchronizing equations (3) and (5), following equation is obtained:

$$
\ln M C=a+b \ln O I+c \ln R_{i}+c^{\prime} \frac{I D}{R_{i}}+d \ln E x+e \ln C E+f D
$$

where $c^{\prime}=c z$. Therefore, assimilation capacity $z$ can be identified as follows:

$$
z=\frac{c^{\prime}}{c}
$$

Utilizing equation (6), governing factors of UPM's MC taking assimilated innovation resources over the period from 1990-2017 was analyzed as demonstrated in Table 10.

Table 10. Governing factors of UPM's MC taking assimilated external innovation resources (1990-2017).

$$
\begin{aligned}
\ln M C= & 2.02+0.19 \ln O I+0.74 D_{1} \ln R_{i}+0.42 D_{2} \ln R_{i}+0.22 \frac{I D}{R_{i}}+0.32 \ln E x+0.12 D_{1} \ln C E+0.22 D_{2} \ln C E \\
& (2.42)^{*}(4.89)
\end{aligned}
$$

$D$ : dummy variables $\left(D_{1}: 1990-2010=1\right.$, others $=0 ; D_{2}: 2011-2017=1$, others $=0$; $D_{3}: 2009,2010,2012=1$, others $=0 ; D_{4}: 1993,2001=1$, others $=0$ )

The figures in parentheses indicate $t$-statistics: all are significant at the $1 \%$ level except $* 5 \%$ level. 
From Table 10 assimilation capacity can be identified as summarized in Table 11. Table 11.

Assimilation capacity in UPM.

$\begin{array}{lll}1990-2010 & 0.30 & (0.22 / 0.74) \\ 2011-2017 & 0.52 & (0.22 / 0.42)\end{array}$

\subsection{EFFECT OF CO-Evolutionary COUPLING WITH DOWNSTREAM}

Tables 10 and 11 suggest a possible casualty between increase in assimilation capacity and effect of downstream in inducing UPM's MC as illustrated in Fig. 10.

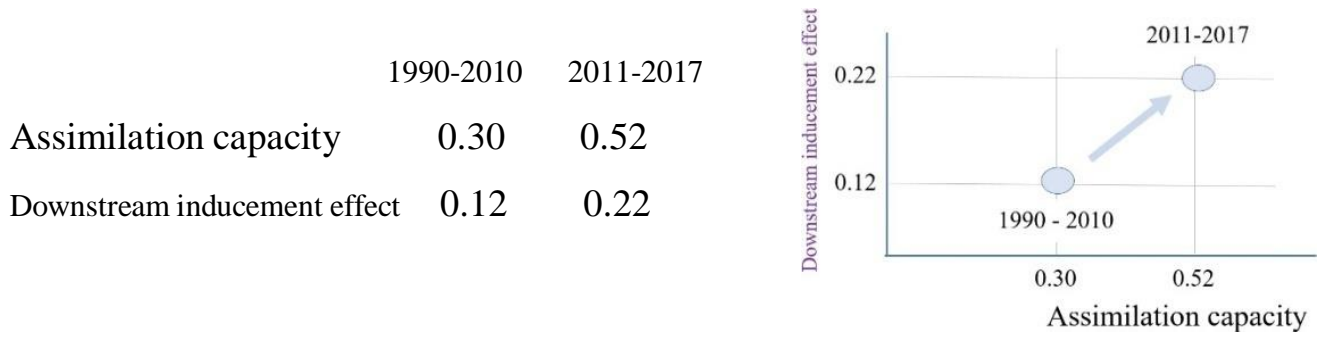

Figure 10. Correlation between assimilation capacity and downstream inducement effect in UPM.

This suggests co-evolutionary coupling with downstream. This can be demonstrated by the significant impact of downstream on UPM's R\&D price (price of gross R\&D) increase as follows: Under the competitive circumstances where UPM seeks profit maximum, R\&D price $p_{R}$ can be depicted as follows:

$p_{R}=M P R M C * p_{M C}$

This price increased dramatically after transforming into circular economy-based business model in 2011 as demonstrated in Fig. 11.

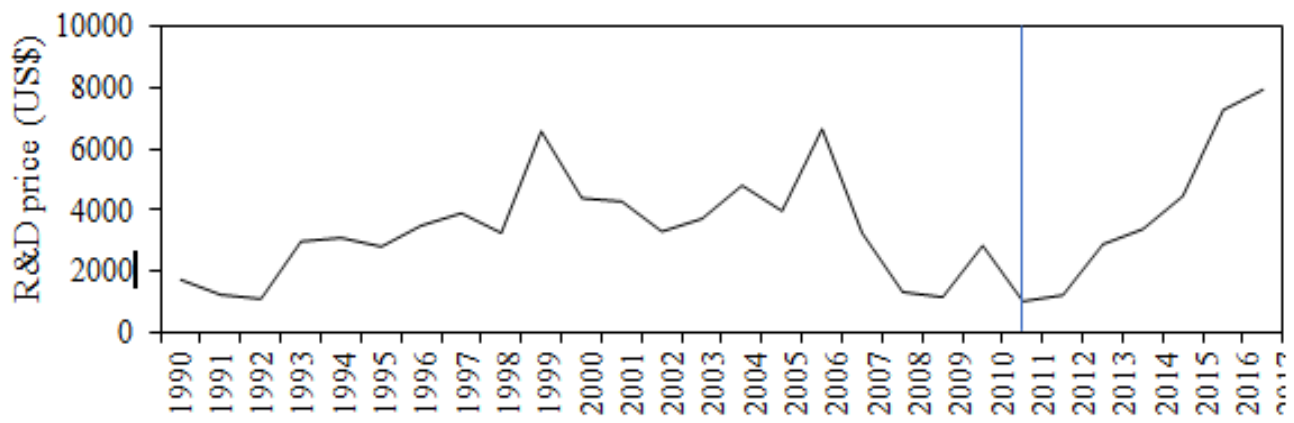

Figure 11. Trend in UPM's gross R\&D price (1990 - 2017).

Fig. 12 and Table 12 analyze correlation between coupling effect and price of UPM's gross R\&D which demonstrate that coupling effect induced the price increase significantly after 2011. 
International Journal of Managing Information Technology (IJMIT) Vol.11, No.2, May 2019

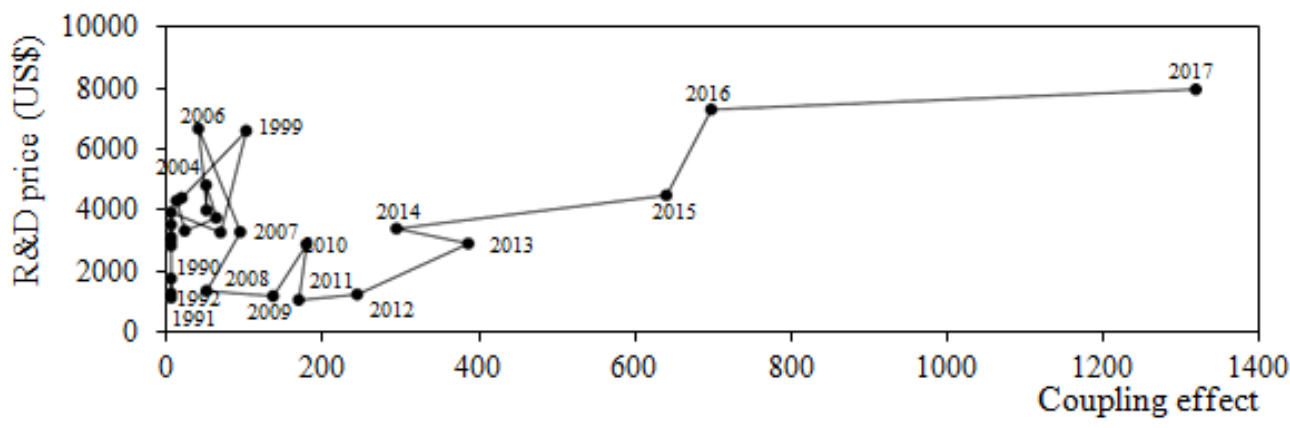

Figure 12. Correlation between coupling effect and R\&D price in UPM (1990-2017).

Table 12. Correlation between coupling effect and R\&D price in UPM (1990-2017).

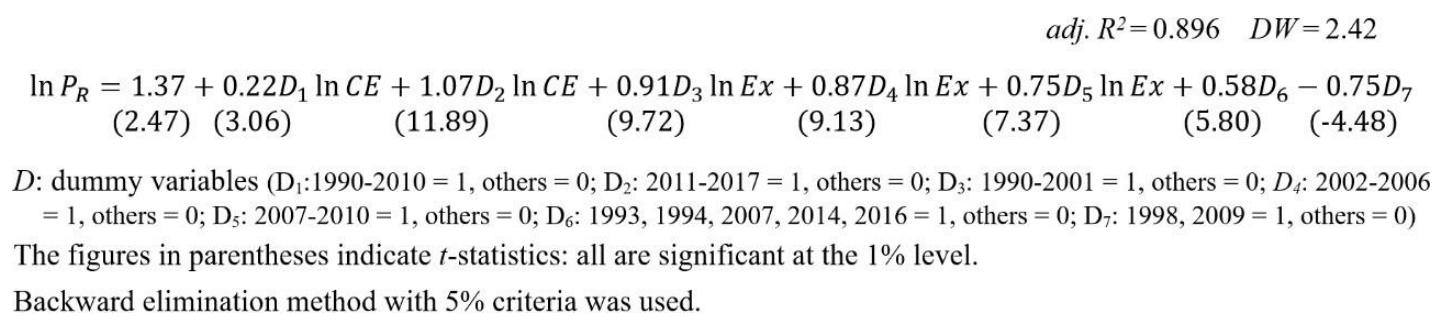

Such increase in UPM's gross R\&D price can be attributed to effective utilization of assimilated SIRs. Table 13 demonstrates that coupling effect induced assimilated SIRs significantly.

Table 13. Correlation between coupling effect and assimilated SIRs in UPM (1990-2017).

$$
\begin{array}{rlrl}
\ln z S I R_{S}= & 1.24+0.39 D_{1} \ln C E+0.42 D_{2} \ln C E-2.67 D_{3} & \text { adj. } R^{2}=0.893 & D W=1.01
\end{array}
$$

$D$ : dummy variables $\left(D_{I}: 1990-2010=1\right.$, others $=0 ; D_{2}: 2011-2017=1$, others $=0 ; D_{3}: 1990,1991,1992,1993,1994=1$, others $=0$ ) The figures in parentheses indicate $t$-statistics: all are significant at the $1 \%$ level.

Fig. 13 and Table 14 analyze correlation between PSR and coupling effect in UPM which demonstrates significant correlation after 2011. Advanced PSR activates coupling effect in the downstream, thereby co-evolutionary coupling between up-down stream emerged after 2011 when UPM moved toward a circular economy.

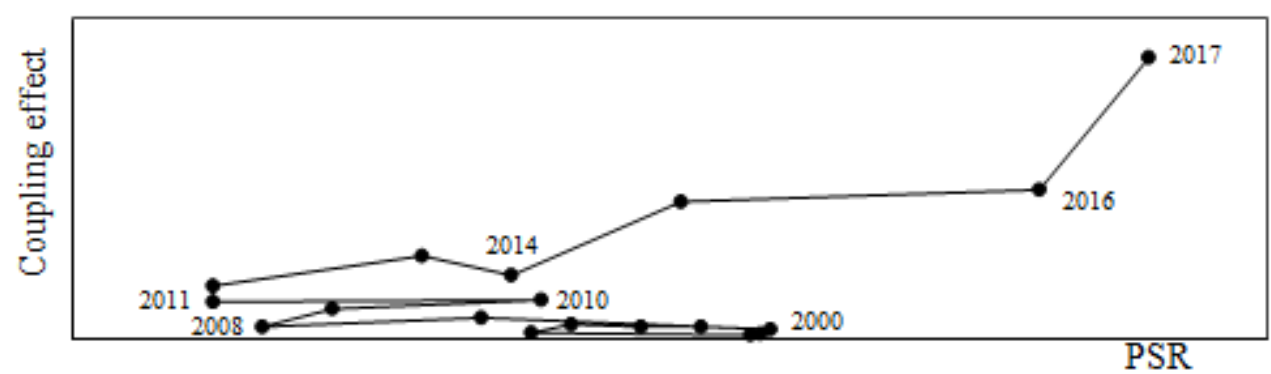

Figure 13. Correlation between PSR and coupling effect in UPM (2000-2017). 
Table 14. Correlation between PSR and coupling effect in UPM (2000-2017)

$$
\text { adj. } R^{2}=0.806 \quad D W=2.33
$$

$$
\begin{gathered}
\ln C E=6.27-0.09 D_{11} \ln P S R+0.02 D_{12} \ln P S R+1.23 D_{2} \ln P S R-2.63 D_{3} \\
(26.21)(-6.00)
\end{gathered}
$$
(26.21) (-6.00)
(2.47)
$(-7.36)$

$D$ : dummy variables $\left(D_{I I}: 2000-2006=1\right.$, others $=0 ; D 1_{2}: 2007-2010=1$, others $=0 ; D_{2}: 2011-2017=1$, others $=0 ; D_{3}: 2000,2001,2005,2006$ $=1$, others $=0$ )

The figures in parentheses indicate $t$-statistics: all are significant at the $1 \%$ level.

On the basis of the foregoing analyses, Fig. 14 demonstrates co-evolutionary coupling that UPM demonstrated. R\&D induced MC, which induced sales and PSR. Increased sales induced R\&D, which, together with assimilated SIRs increased R\&D price leading to PSR increase. Increased PSR activated coupling effect in the downstream, which increased $R \& D$ price.

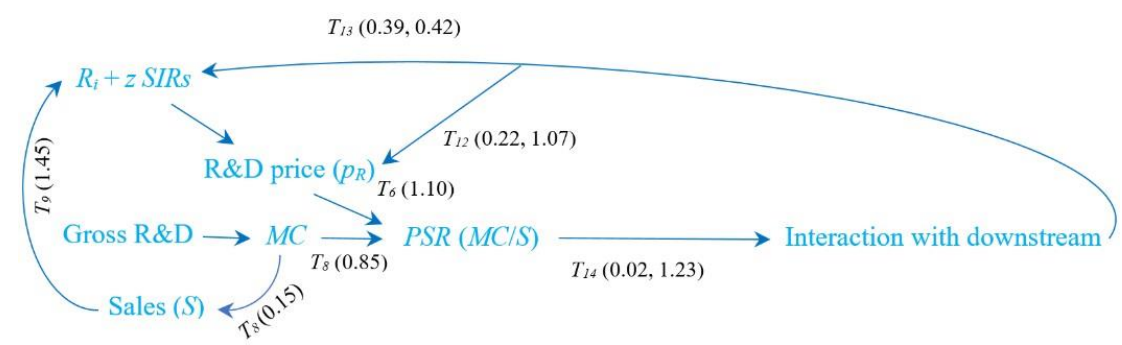

Figure 14. Co-evolutionary coupling in UPM (1990-2017).

$T_{n}$ means Table number, and figures indicate elasticity (1990-2010 and 2011-2017, or 1990-2017).

\section{CONClusion}

Driven by digital solutions, together with the long-lasting goal of transition from a traditional fossil economy to a circular economy, the coupling of digitalization and bioeconomy is leading towards a digitalized bioeconomy that can satisfy the shift in people's preferences for ecoconsciousness, which in turn induces coupling of up-down stream operation in the value chain.

This dual coupling has led to a new R\&D model that absorbs external innovation resources from a broad value chain, identical to the forest-based bioeconomy, and assimilates them into various business entities.

In light of the increasing significance of such a new $R \& D$ model that may avoid the dilemma between $R \& D$ expansion and productivity decline, this paper elucidated a dynamism enabling such a dual coupling.

An empirical analysis of leading global forest-based bioeconomy firms was conducted with special attention to the relevance of geopolitical regions fatal to foot-tight nature of the forestbased-bioeconomy.

It was identified that in line with the advancement of the digital economy, bioeconomy firms have been amidst transforming endeavors in the global new stream, which inevitably identify leaders of geopolitical regions by respective growth potential and business prospects.

KC, UPM, Oji and Sappi represent America, Europe, Asia and Africa, respectively.

Among four leaders, UPM demonstrates a sophisticated R\&D-driven co-evolutional cycles utilizing external resources both downstream and external market with (i) Sophisticated R\&D system in inducing MC, (ii) Well balanced resources allocation to MC creation, and (iii) Effective utilization of external resources in downstream and external market. This can be attributed to its balanced contribution structure by $\mathrm{R} \& \mathrm{D}, O I$, coupling effect with downstream and also external 
market conditions. With this structure, UPM's R\&D induces MC, which in turn induces sales and PSR. Increased sales induce R\&D, which, together with assimilated SIRs increases its price leading to PSR increase. Increased PSR activated coupling effect in the downstream, which in turn increases R\&D price. Thus, co-evolutionary coupling of digitalization and the bioeconomy, and also of up-down stream operation in the value chain have been created.

These findings give rise to the following insightful suggestions with respect to dynamism for a new R\&D model beyond the existing concept of the digital innovation:

(i) Dual co-evolutional coupling should be applied to disruptive business model aiming at overcoming the dilemma between R\&D expansion and productivity decline.

(ii) Dynamism enabling co-evolutionary coupling with the vigor of downstream should be elucidated and conceptualized.

(iii) New four-dimensional sphere beyond the existing concept of the digital innovation should be applied in the platform ecosystem.

(iv) Co-evolutional innovation among digital innovation, paradigm change and shift in people's preferences should be further elaborated by taking dual co-evolutional coupling concept.

Future work should focus on further elucidation, conceptualization and operationalization of the functions that the dual co-evolutional coupling play similar role of artificial intelligence (AI), machine learning, virtual reality (VR), and augmented reality (AR)

\section{ACKNOWLEDGEMENTS}

The research leading to these results is the part of a project: Platform Value Now: Value capturing in the fast emerging platform ecosystems, supported by the Strategic Research Council at the Academy of Finland [grant number 293446]. 
International Journal of Managing Information Technology (IJMIT) Vol.11, No.2, May 2019

APPENDIX

Basic Statistics For The AnAlysis

Table A1. Top 50 global forest-based bioeconomy firms in 2017 (by OI order).

\begin{tabular}{|c|c|c|c|c|c|c|c|c|}
\hline Firm Name & Short Name & Country & OI & Sales & $\mathbf{R \& D}$ & $\mathbf{O I} / \mathbf{S}$ & $\mathbf{R} / \mathbf{S}$ & OI/R \\
\hline Kimberly-Clark & $\mathrm{KC}$ & US & 3299 & 18259 & 311 & 0.18 & 0.017 & 10.61 \\
\hline International Paper & Int. Paper & US & 2069 & 21743 & 28 & 0.10 & 0.001 & 73.89 \\
\hline UPM-Kymmene & UPM & Finland & 1419 & 11285 & 57 & 0.13 & 0.005 & 24.89 \\
\hline Mondi Group & Mondi & UK & 1148 & 8000 & 26 & 0.14 & 0.003 & 44.15 \\
\hline Shandong Chenming & Shandong & China & 1023 & 4417 & 151 & 0.23 & 0.034 & 6.80 \\
\hline Stora Enso & Stora & Finland & 1019 & 11325 & 143 & 0.09 & 0.013 & 7.13 \\
\hline Packaging Corp of America & Packaging & US & 931 & 6445 & 13 & 0.14 & 0.002 & 71.62 \\
\hline Smurfit Kappa & Smurfit & Ireland & 924 & 9653 & 8 & 0.10 & 0.001 & 115.50 \\
\hline Hengan International & Hengan & Hong Kong & 780 & 2933 & 61 & 0.27 & 0.021 & 12.79 \\
\hline Unicharm & Unicharm & Japan & 774 & 5721 & 58 & 0.14 & 0.010 & 13.34 \\
\hline West Fraser Timber & WFT & Canada & 670 & 3955 & 11 & 0.17 & 0.003 & 60.91 \\
\hline Metsaliitto & Metsä & Finland & 655 & 5682 & 20 & 0.12 & 0.004 & 32.75 \\
\hline Oji Paper & Oji & Japan & 633 & 12838 & 83 & 0.05 & 0.006 & 7.63 \\
\hline DS Smith & DS & UK & 570 & 6153 & 9 & 0.09 & 0.001 & 63.33 \\
\hline Sappi & Sappi & South Africa & 526 & 5296 & 30 & 0.10 & 0.006 & 17.53 \\
\hline Shan Dong Sun Paper & Shan Sun & China & 523 & 2796 & 112 & 0.19 & 0.040 & 4.67 \\
\hline Arauco) & Arauco & Chile & 491 & 5238 & 3 & 0.09 & 0.000 & 188.85 \\
\hline Sumitomo Forestry & Sumitomo & Japan & 481 & 9926 & 17 & 0.05 & 0.002 & 28.29 \\
\hline Klabin & Klabin & Brazil & 473 & 2624 & 7 & 0.18 & 0.003 & 67.57 \\
\hline Canfor & Canfor & Canada & 429 & 3589 & 11 & 0.12 & 0.003 & 39.00 \\
\hline Lenzing & Lenzing & Austria & 403 & 2547 & 29 & 0.16 & 0.011 & 13.90 \\
\hline Sonoco & Sonoco & US & 367 & 5037 & 21 & 0.07 & 0.004 & 17.48 \\
\hline Graphic Packaging & Graphic & US & 343 & 4404 & 14 & 0.08 & 0.003 & 23.82 \\
\hline Svenska Cellulosa & SCA & Sweden & 294 & 1949 & 6 & 0.15 & 0.003 & 49.00 \\
\hline Billerud & Billerud & Sweden & 262 & 2614 & 14 & 0.10 & 0.005 & 18.71 \\
\hline Cheng Loong & Cheng & Taiwan & 254 & 1434 & 3 & 0.18 & 0.002 & 84.67 \\
\hline Holmen & Holmen & Sweden & 253 & 1887 & 11 & 0.13 & 0.006 & 23.00 \\
\hline Mayr-Melnhof Karton & Mayr & Austria & 242 & 2635 & 3 & 0.09 & 0.001 & 80.67 \\
\hline Sodra & Sodra & Sweden & 224 & 2400 & 11 & 0.09 & 0.005 & 20.36 \\
\hline Sveaskog & Sveaskog & Sweden & 214 & 726 & 3 & 0.29 & 0.004 & 71.33 \\
\hline $\begin{array}{l}\text { SCG Packaging (Formerly Siam Pulp } \\
\text { and Paper) }\end{array}$ & SCG & Thailand & 212 & 2517 & 123 & 0.08 & 0.049 & 1.72 \\
\hline Rengo & Rengo & Japan & 211 & 4863 & 13 & 0.04 & 0.003 & 16.23 \\
\hline Daio Paper & Daio & Japan & 210 & 4254 & 26 & 0.05 & 0.006 & 8.08 \\
\hline ENCE & ENCE & Spain & 169 & 834 & 1 & 0.20 & 0.001 & 169.00 \\
\hline Mercer International & Mercer & Canada & 167 & 1169 & 3 & 0.14 & 0.003 & 55.67 \\
\hline Nippon Paper Group & Nippon & Japan & 157 & 9330 & 56 & 0.02 & 0.006 & 2.80 \\
\hline Cascades & Cascades & Canada & 135 & 3329 & 4 & 0.04 & 0.001 & 33.75 \\
\hline Schweitzer-Mauduit & Schweitzer & US & 125 & 982 & 18 & 0.13 & 0.018 & 7.02 \\
\hline
\end{tabular}


International Journal of Managing Information Technology (IJMIT) Vol.11, No.2, May 2019

\begin{tabular}{|l|l|l|l|l|l|l|l|l|}
\hline Ahlstrom & Ahlstrom & Finland & 117 & 2210 & 20 & 0.05 & 0.009 & 5.85 \\
\hline Hokuetsu Paper & Hokuetsu & Japan & 115 & 2339 & 7 & 0.05 & 0.003 & 16.43 \\
\hline Yuen Fong Yu Paper & Yuen Fong & Taiwan & 100 & 1979 & 8 & 0.05 & 0.004 & 12.50 \\
\hline Heinzel Holding & Heinzel & Austria & 83 & 2048 & 1 & 0.04 & 0.000 & 166.00 \\
\hline Moorim group & Moorim & Korea & 81 & 886 & 3 & 0.09 & 0.003 & 27.00 \\
\hline The Lecta Group & Lecta & UK & 75 & 1645 & 6 & 0.05 & 0.004 & 12.50 \\
\hline The Pack Corporation & Pack Corp. & Japan & 65 & 805 & 13 & 0.08 & 0.016 & 5.00 \\
\hline $\begin{array}{l}\text { Resolute Forest Products (Formerly } \\
\text { Abitibi Bowater) }\end{array}$ & Resolute & Canada & 49 & 3513 & 18 & 0.01 & 0.005 & 2.66 \\
\hline Ballarpur Industries & Ballarpur & India & 47 & 333 & 7 & 0.14 & 0.021 & 6.71 \\
\hline Mitsubishi Paper & Mitsubishi & Japan & 38 & 1800 & 9 & 0.02 & 0.005 & 4.22 \\
\hline Corticeira Amorim & Corticeira & Portugal & 25 & 797 & 8 & 0.03 & 0.010 & 3.13 \\
\hline Domtar & Domtar & Canada & -317 & 5157 & 24 & -0.06 & 0.005 & -13.21 \\
\hline
\end{tabular}

OI: operating income, R\&D: research and development, S: sales

Forest-based bioeconomy firms encompass forest, paper and packaging firms Sales, R\&D and OI unit: mil. US\$ (nominal).

OECD exchange rate was used to convert the currency units into US\$. Source: Firm's Annual report 2017.

Table A2. Techno-market indicators in leading 4 firms (2000-2017).

\begin{tabular}{|c|c|c|c|c|c|c|c|c|c|c|c|c|}
\hline & \multicolumn{3}{|c|}{ KC } & \multicolumn{3}{|c|}{ UPM } & \multicolumn{3}{|c|}{ Oji } & \multicolumn{3}{|c|}{ Sappi } \\
\hline Year & $\mathrm{MC} / \mathrm{R}$ & $\mathrm{MC} / \mathrm{OI}$ & $\mathrm{MC} / \mathrm{S}$ & $\mathrm{MC} / \mathrm{R}$ & $\mathrm{MC} / \mathrm{OI}$ & $\mathrm{MC} / \mathrm{S}$ & $\mathrm{MC} / \mathrm{R}$ & $\mathrm{MC} / \mathrm{OI}$ & $\mathrm{MC} / \mathrm{S}$ & $\mathrm{MC} / \mathrm{R}$ & $\mathrm{MC} / \mathrm{OI}$ & $\mathrm{MC} / \mathrm{S}$ \\
\hline 2000 & 106.34 & 11.20 & 0.47 & 215.97 & 5.11 & 0.99 & 58.89 & 24.76 & 0.59 & 118.13 & 2.64 & 0.38 \\
\hline 2001 & 111.75 & 14.11 & 0.44 & 215.14 & 6.00 & 0.98 & 43.48 & 7.51 & 0.43 & 99.60 & 8.33 & 0.48 \\
\hline 2002 & 111.07 & 13.03 & 0.42 & 173.06 & 9.24 & 0.76 & 50.39 & 16.85 & 0.50 & 133.65 & 6.65 & 0.72 \\
\hline 2003 & 94.08 & 11.32 & 0.53 & 164.93 & 21.52 & 0.80 & 36.98 & 8.27 & 0.39 & 160.00 & 11.18 & 0.71 \\
\hline 2004 & 116.91 & 13.05 & 0.46 & 182.50 & 12.52 & 0.87 & 59.65 & 9.68 & 0.61 & 151.67 & 16.94 & 0.67 \\
\hline 2005 & 93.27 & 12.90 & 0.53 & 173.30 & 27.25 & 0.93 & 51.83 & 6.99 & 0.50 & 98.22 & 15.87 & 0.53 \\
\hline 2006 & 94.02 & 13.46 & 0.59 & 228.24 & 18.65 & 1.00 & 57.98 & 9.66 & 0.59 & 77.08 & 14.80 & 0.37 \\
\hline 2007 & 110.11 & 11.66 & 0.60 & 142.51 & 14.66 & 0.71 & 55.84 & 10.13 & 0.50 & 64.59 & 5.73 & 0.41 \\
\hline 2008 & 83.84 & 9.78 & 0.78 & 95.17 & 11.88 & 0.49 & 39.33 & 10.85 & 0.34 & 42.21 & 4.57 & 0.24 \\
\hline 2009 & 72.09 & 7.68 & 0.88 & 89.68 & 11.88 & 0.56 & 39.79 & 12.40 & 0.32 & 64.03 & 10.18 & 0.37 \\
\hline 2010 & 78.23 & 8.94 & 0.80 & 151.74 & 9.10 & 0.77 & 43.85 & 5.36 & 0.34 & 105.56 & 7.74 & 0.40 \\
\hline 2011 & 82.59 & 10.69 & 0.80 & 88.73 & 9.74 & 0.44 & 42.15 & 5.90 & 0.34 & 59.04 & 17.85 & 0.21 \\
\hline 2012 & 92.98 & 12.32 & 0.64 & 102.67 & 3.52 & 0.44 & 41.62 & 7.32 & 0.33 & 61.83 & 3.52 & 0.23 \\
\hline 2013 & 103.33 & 11.60 & 0.57 & 172.56 & 11.85 & 0.65 & 36.18 & 6.58 & 0.28 & 44.64 & 7.32 & 0.22 \\
\hline 2014 & 113.04 & 16.50 & 0.47 & 209.49 & 10.78 & 0.74 & 41.80 & 7.36 & 0.34 & 70.80 & 5.85 & 0.34 \\
\hline 2015 & 119.14 & 15.71 & 0.48 & 248.55 & 8.05 & 0.91 & 46.81 & 10.49 & 0.34 & 54.96 & 4.31 & 0.29 \\
\hline 2016 & 150.91 & 14.92 & 0.37 & 313.05 & 10.97 & 1.27 & 46.21 & 6.05 & 0.31 & 107.54 & 5.74 & 0.54 \\
\hline 2017 & 146.62 & 13.82 & 0.40 & 273.30 & 10.98 & 1.38 & 55.47 & 7.27 & 0.36 & 123.15 & 6.91 & 0.69 \\
\hline
\end{tabular}

MC: market capitalization, R: research and development, S: sales, OI: operating income Source: Firm's Annual reports. 
Table A3. Trend in market capitalization in leading 4 firms (2000-2017).

\begin{tabular}{|c|c|c|c|c|}
\hline Year & KC & UPM & Oji & Sappi \\
\hline 2000 & 36465.07 & 10160.64 & 5879.31 & 3660.21 \\
\hline 2001 & 39882.55 & 9722.39 & 4036.96 & 3823.85 \\
\hline 2002 & 38208.30 & 8326.85 & 4424.85 & 4571.52 \\
\hline 2003 & 30809.30 & 9915.19 & 3781.66 & 4914.46 \\
\hline 2004 & 37140.26 & 11752.58 & 6224.58 & 4833.39 \\
\hline 2005 & 32791.37 & 11777.76 & 5120.93 & 3816.57 \\
\hline 2006 & 30212.59 & 13594.53 & 5890.12 & 2505.65 \\
\hline 2007 & 31717.17 & 10212.24 & 5230.00 & 2732.47 \\
\hline 2008 & 25395.52 & 7005.25 & 4295.18 & 1640.67 \\
\hline 2009 & 21965.03 & 6029.41 & 4293.76 & 2111.07 \\
\hline 2010 & 24800.00 & 9104.64 & 4516.16 & 2639.00 \\
\hline 2011 & 25572.03 & 6054.94 & 4887.16 & 1440.88 \\
\hline 2012 & 31843.85 & 5638.47 & 5075.49 & 1323.11 \\
\hline 2013 & 35219.46 & 7966.25 & 3608.53 & 1106.13 \\
\hline 2014 & 38692.47 & 8749.22 & 4351.36 & 1611.38 \\
\hline 2015 & 35446.67 & 9082.23 & 4029.01 & 1164.99 \\
\hline 2016 & 44883.60 & 12179.75 & 4058.57 & 1982.24 \\
\hline 2017 & 40695.39 & 13647.66 & 4552.42 & 2440.51 \\
\hline
\end{tabular}

Market capitalization unit: mil. US\$ (real values based on 2010). World bank GDP deflator was used. OECD exchange rate was used to convert the currency units into US\$. Source: Firm's Annual reports.

\section{REFERENCES}

[1] Watanabe, C., Naveed, N. and Neittaanmäki, P., 2018d. Digitalized Bioeconomy: Planned Obsolescence-driven Economy Enabled by Co-evolutionary Coupling. Technology in Society 56, 8-30.

[2] Watanabe, C., 1973. Ecological Analysis of Japanese Economy. The Economic S eminar 211, 2943.

[3] Ministry of International Trade and Industry (MITI), Japan, 1972a. Ecology and Application of Its Concept to Industrial Policy. MITI Journal 5 (2), 63-68.

[4] Watanabe, C., 1972. A Guideline to the Ecolo-utopia: Basic Suggestion to Japanese Economy in the Face of the New Crisis. Analyst 9, 34-56.

[5] Watanabe, C., 1999. Systems Option for Sustainable Development: Effect and Limit of the Ministry of International Trade and Industry's Efforts to Substitute Technology for Energy. Research Policy, 28 (7), 719-749.

[6] Ministry of International Trade and Industry (MITI), Japan, 1972b. Industry-Ecology: Introduction of Ecology into Industrial Policy. MITI, Tokyo.

[7] Finnish Forest Industries Federation, 2012. Forest Industry Regenerating through Innovation, https://www.forestindustries.fi/ Retrieved 8 April. 2018.

[8] Hetemäki, L., Hoen, H.F., and Schwarzbauer, P., 2014. Future of the European Forest-based Sector and Bioeconomy, in Hetemaki, L. edt., Future of the European Forest-based Sector: Structural Changes towards Bioeconomy. European Forest Institute, Joensuu.

[9] Hetemäki, L., 2016. Role of Sustainable Forest-based Bioeconomy in Europe. Think Forest, 15 November 2016, Brussels.

[10] Watanabe, C., Naveed, N., and Neittaanmäki, P., 2018a. Digital Solutions Transform the Forest- 
based Bioeconomy into a Digital Platform Industry: A Suggestion for a Disruptive Business Model in the Digital Economy. Technology in Society 54, 168-188.

[11] VTT Visions 11, 2017. Bittejä ja Biomassaa: Tiekartta Digitalisaation Vauhdittamaan Biotalouteen. Juvenes Print, Helsinki.

[12] Tieto, 2017. UPM Biochemicals Targets to Enhance its Global Market Reach a nd Business Agility Through New B2B eCommerce Solution by Tieto. https://w ww.tieto.com/news/upmbiochemicals-targets-to-enhance-its-global-market-reach-an d-business-agility-through-new-b2b Retrieved 02 August, 2018.

[13] Tieto, 2018. Amazon Web Services - public cloud. https://www.tieto.com/node/85026/awspubliccloud Retrieved 02 August, 2018.

[14] EC (European Commission), Innovating for Sustainable Growth: a Bioeconomy for Europe. $\operatorname{COM}(2012) 60$ Final, (2012) Brussels.

[15] Ministry of Economic Affairs and Employment of Finland (MEE), 2014. The Finnish Bioec onomy Strategy, Ministry of Economic Affairs and Employment of Finland.

[16] Ellen Macarthur Foundation (EMF), 2015. Towards a Circular Economy: Business Rationale for an Accelerated Transition. EMF, Cowes, UK.

[17] Wolfslehner, B., Linser, S., Pulzl. H., Bastrup-Birk, A., Camia, A and Marchetti, M., 2016. Forest Bioeconomy - A New Scope for Sustainability Indicators. European Forest Institute. From Science to Policy 4, 1-31.

[18] MISTRA, 2017. Bioeconomy and Digitalization. MISTRA, Stockholm.

[19] Watanabe, C., Tou, Y., and Neittaanmäki, P., 2018b. A New Paradox of the Digital Economy: Structural Sources of the Limitation of GDP Statistics. Technology in Society 55, 9-23.

[20] Watanabe, C., Naveed, K., Tou, Y., and Neittaanmäki, P., 2018c. Measuring GDP in the Digital Economy: Increasing Dependence on Uncaptured GDP. Technological Forecasting and Social Change 137, 226-240.

[21] Bae, S.C. and Kim, D., 2003. The Effect of R\&D Investments on Market Value of Firms: Evidence from the U.S., Germany, and Japan. The Multinational Business Review, 11 (3), 51-77.

[22] Obeng, G.K. and Bao, H.P., 2014. Consideration of Technological Obsolescence in Quantitative Forecasting and Economic Life Analysis. International Conference on Engineering and Applied Sciences Optimization, Kos Island, Greece.

[23] Satyro, W.C., Sacomano, J.B., and Contador, J.C., 2018. Planned Obsolescence or Planned Resource Depletion? A Sustainable Approach. Journal of Cleaner Production, 195, 744-752.

[24] Pelli, P., Haapala, A. and Pykalainen, J., 2017. Services in the Forest-based Bioeconomy: Analysis of European Strategies. Scandinavian Journal of Forest Research, online 17 Feb March 2017.

[25] UPM, 2016. Aiming Higher with Biofore: Annual Report 2016. http://hugin.info/165629/R/2081401/784910.pdf Retrieved 30 June 2017.

[26]UPM, 2017a. UPM Kaukas Leads the Way in Promoting the Circular Economy. Biofore, 23 May 2017.

[27] UPM, 2017b. Aiming Higher with Biofore: Annual Report 2017.

[28] UPM, 2018. UPM Circular Economy, http://www.upm.com/circulareconomy/Pages/default.aspx Retrieved 02 August 2018.

[29] Tou, Y., Watanabe, C., Moriya, K. and Neittaanmäki, P., 2018. Neo Open Innovation in the Digital Economy: Harnessing Soft Innovation Resources. International Journal of Managing Information Technology 10 (4), 53-75.

[30] Tou, Y., Watanabe, C., Moriya, K. and Neittaanmäki, P., 2019. Harnessing Soft Innovation Resources Leads to Neo Open Innovation. Technology in Society, in print. 


\section{Authors}

Nasir Naveed is currently a Ph.D. student in the Faculty of Information Technology, University of Jyväskylä, Finland. He graduated from the Tampere University of Technology, Finland in Industrial Engineering and Management.(nn.ghumman@gmail.com)

Chihiro Watanabe graduated from the University of Tokyo, Japan, and is currently Professor Emeritus at the Tokyo Institute of Technology, a research professor at the University of Jyväskylä, Finland, and a research scholar at the International Institute for Applied Systems Analysis (IIASA). (watanabe.c.pqr@gmail.com).

Pekka Neittaanmäki graduated from the University of Jyväskylä with a degree in Mathematics. He is currently Professor of the Faculty of Information Technology, University of Jyväskylä, Finland. (pekka.neittaanmaki@jyu.fi). 